\title{
Decision Support System for Evaluation of Peatland Agroecology Suitability in Pineapple Plants
}

\author{
Fiqhri Mulianda Putra' ${ }^{1}$, Imas Sukaesih Sitanggang ${ }^{2}$, Sobir $^{3}$ \\ ${ }^{1}$ Department of Computer Science, Faculty of Mathematics and Natural Sciences, \\ IPB University, Bogor, Indonesia \\ ${ }^{2,3}$ Deparment of Agronomy and Horticulture, Faculty of Agriculture, \\ IPB University, Bogor, Indonesia \\ Email: ${ }^{1}$ fiqhri_mulianda@apps.ipb.ac.id, ${ }^{2}$ imas.sitanggang@ipb.ac.id, ${ }^{3}$ rsobir@yahoo.com
}

\begin{abstract}
A Pineapple (Ananas comosus (L.) Merr.) It is one of the leading commodities in the Indonesian horticultural sub-sector. Based on data from PDSIP in the last 5 years the development of pineapple production has increased but not too high as well as the harvested area. One of the areas that cultivate pineapple plants in Riau Province is Kampar Regency. Its production in 2015 was 8,482 tons, down from 20,046 tons in 2013. However, this amount is not optimal considering the area in Kampar Regency is still large enough for pineapple cultivation. Kampar District has a potential peatland of around 191,363 ha. About half of the area is thin peat, while the rest varies from moderate to deep peat. The success or failure of peatland management for cultivated land is highly dependent on the condition of its characteristics and the mastery and scientific understanding of the character of peat. This shows the need to evaluate the carrying capacity of land-based on its suitability so that it can be used as a guide in wise land-use planning. This study aims to create a fuzzy inference system model with Mamdani method in determining the agroecological suitability of peatlands for pineapple plants, this is due to the target class of land suitability parameters based on FAO provisions, namely S1, S2, S3, and N. Based on the obtained model, decision support systems will be developed for the suitability of peatland agroecology for pineapple plants.
\end{abstract}

Keywords: Fuzzy Inference System, Fuzzy Mamdani, Peatland, Pineapple

\section{INTRODUCTION}

Pineapple (Ananas comosus (L.) Merr.) It is one of the leading commodities in the Indonesian horticultural sub-sector. The development of pineapple production has increased, but not very high in the last five years, as has the harvest area. If in 1980 Indonesia's pineapple production reached 180.64 thousand tons, then in 2015 it had reached 1.73 million tons. Increased pineapple production in Java in this period was higher than outside Java, but since 2007 pineapple production in Java has decreased. Then in 2011-2015, Pineapple production in Java only rose $2.42 \%$ per year, while outside Java, it still rose an average of $6.75 \%$ per year [1].

Furthermore, in 2011-2015 the pineapple harvest area was relatively stagnant with an average growth of $2.43 \%$ per year, while the growth of pineapple harvest areas outside Java decreased by $0.99 \%$ per year, while the average pineapple harvest area in Java rose by $18.17 \%$ per year, but yields have not been able to match the harvested area of 1980-1996 [1]. So it looks inversely proportional to the development of pineapple 
production outside Java which increases, but the harvest area decreases between 20112015.

Based on data from the Riau Statistics Agency, pineapple production in Riau Province in 2015 amounted to 74,388 tons, down from 2013 which amounted to 96,173 tons [2]. According to Nugroho et al. pineapple cultivation is considered profitable, given the production costs are not too expensive and the community's need for pineapple is increasing[3]. One of the areas that cultivate pineapple plants in Riau Province is Kampar Regency. Based on data from the Riau Central Statistics Agency [2], the production of Kampar Regency in 2015 was 8,482 tons, down from 2013 by 20,046 tons. However, this number is not maximal considering that the area in Kampar Regency is still large enough for pineapple cultivation.

Kampar District has a potential peatland of around 191,363 ha. About half of the area is thin peat, while the rest varies from moderate to deep peat. At present, peat in Kampar District has been managed for cultivation areas, both for food crops as well as for plantation and industrial plants. The success or failure of peatland management for cultivated land is very dependent on the characteristics and mastery conditions and scientific understanding of the character of peat [4]. This shows the need to evaluate the carrying capacity of land-based on its suitability so that it can be used as a guide in wise land-use planning [5]. To achieve optimal production, pineapple plants must be planted in soil that is by plant growth requirements. Land suitability assessments are needed to obtain information about suitable soil quality and characteristics to determine the level of management needed [3].

Several studies relating to land suitability include research by Yanter et al. [6] conducted a study on the selection of the best alternative plants with suitable land in Sikka Regency using the fuzzy analytic hierarchy process method and the Mamdani fuzzy inference system by building intelligent decision support systems that get good land suitability classification results. The research by Sitorus [7] examined the evaluation of land suitability for pineapple plants in the South Kualuh District, Labuhanbatu Utara Regency with a survey method on the soil map unit. Research by Riyandani [8] evaluates the suitability of land for various types of plants on peatlands in Arut Selatan Regency, Kotawaringin Barat District based on survey methods by taking data samples using purposive sampling that considers certain conditions on the land to be studied.

Research by Hartati and Sitanggang [9] examines knowledge-based systems to achieve physical land suitability for 45 crop cultivation according to fuzzy inference. Research by Insani et al. [10] developed an optimization model of fuzzy rules in fuzzy inference systems using artificial neural networks and genetic algorithms used to build expert systems to evaluate the suitability of cereal farms. Research by Pariamanda et al. [11] reviewed the land suitability analysis for coffee plantations in Semarang using the matching and scoring method with the Analytical Hierarchy Process (AHP). Research by Nisyak and Ramdani [12] uses the Multi-Criteria Decision Analysis (MCDA) method for nine criteria (height, slope, rainfall, light intensity, temperature, air humidity, soil type, soil pH, and river). Research by Kunarso and Herdiana [13] on land suitability analysis of liberica coffee species for the development of environmentally 
friendly safety in OKI District using matching and assessment methods using parameters of altitude, soil slope, drainage, rain, air, air, and air security using geographic information systems.

Accurate information related to the Agroecological database is the key to the success of agricultural development planning. According to Soemarno [14], knowledge about the nature and characteristics of soil, agroecology becomes the basis of commodity development and agricultural development efforts. The identification of agroecological characteristics does not match priority. Potential areas for agricultural development and what soil characteristics factors must be monitored so that agricultural products can be optimized. Research by Ramlan et al. [15] conducted a spatial analysis based on GIS for land suitability agroecology in terms of food crop development at a regional scale on Buton Island. Research by Moore et al. [16] conducted a spatial analysis based on GIS using the MCDA method for traditional plant agroecological management in New Zealand.

Based on previous exposure, it can be seen that there is no evaluation of the suitability of peatland agroecology, especially for pineapple plants in Kampar District. Therefore, this study will examine the Decision Support System for the Evaluation of Agroecological Conformity of Pineapple Peatlands using the Fuzzy Mamdani Inference System in processing the quality and characteristics of the land and validation carried out by Experts to maximize the results of the suitability of peatland suitability by assisting farmers and implementing agriculture in determining agriculture suitability of pineapple land.

\section{METHODS}

The study area in this study is Kampar Regency, Riau Province with an area of approximately 1,128,928 ha, which is located between North Latitude to South Latitude and East Longitude, which has peatland potential of around 191,336 ha [2].

\subsection{Research Methods}

This research was conducted using hardware and software as follows:

1. Computer hardware with specifications is Intel CORE i7 8th Gen, 8 GB RAM, 128 GB SSD and 1 TB internal hard drive

2. The software used includes is Python as a programming language, ArcMap version 10.3 as a library for processing and visualizing spatial data, Microsoft Excel 2019 as a supporter of non-spatial data processing.

Stages of research conducted in the research of spatial decision support systems regarding the suitability of peatland agroecology for pineapple plants to be carried out are shown in Figure 1. 


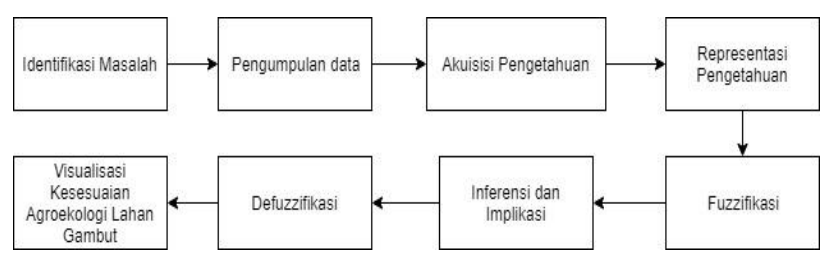

Figure 1. Stages of Research in Spatial Decision Support System

\subsection{Identification Problems}

The development of the system starts with identifying the problem being examined. In this study, the problem to be examined is how to evaluate the suitability of land for pineapple by looking at the requirements and characteristics of pineapple plant growth on peatlands in Kampar District which has potential land for agriculture with the Spatial Decision Support System.

\subsection{Data collection}

At this stage, the literature used as a theoretical basis are books, journals, etc. Correlated with the topic of land suitability evaluation, one of them is a textbook containing information about the land, such as land property and land evaluation guidelines [10]. The book used in this study is a technical guide to evaluating land for agricultural commodities in 2011.

\section{3. Knowledge Acquisition}

Knowledge acquisition is used to obtain the knowledge, facts, rules, and models needed from various sources [17]. Knowledge acquisition in this research is conducting interviews with experts and organizing data from textbooks, then modeling knowledge about the suitability of peatlands with pineapple plants and validating guidance by experts is Prof. Dr. Ir. Sobir, M.Sc from the Department of Agronomy and Horticulture, Faculty of Agriculture, Bogor Agricultural University. After gaining knowledge from various sources, the appropriate method of representation of knowledge is selected for use in modeling and then accepted in the knowledge base.

\subsection{Knowledge Representation}

At this stage, the literature used as a theoretical basis are books, journals, etc. Correlated with the topic of land suitability evaluation, one of them is a textbook containing information about the land, such as land property and land evaluation guidelines [10]. The book used in this study is a technical guide to evaluating land for agricultural commodities in 2011.

\subsection{Fuzzification}

From these results obtained information and strategies to solve problems. At this stage, the solution that can be done is by fuzzy logic, which is a fuzzy inference system using the Mamdani method. In the Mamdani type, the value of each parameter will be calculated in the value of each group of values in each parameter. The calculation of degrees for each parameter is done using the trapezoid formula. The membership value obtained will be an input in the process of evaluating rules based on knowledge. 


\subsection{Inference}

The general form of the rules used is the implication function, for example as an illustration namely: IF ( $\mathrm{X}$ is A) THEN ( $\mathrm{y}$ is $\mathrm{B}$ ), where $\mathrm{x}$ and $\mathrm{y}$ express linguistic variables, while $A$ and $B$ are linguistic values in the form of fuzzy sets. The statement " $\mathrm{x}$ is $\mathrm{A}$ " is an antecedent or premise, while the statement " $\mathrm{y}$ is $\mathrm{B}$ " is called a consequence or conclusion. This proposition can be expanded by using fuzzy operators.

\subsection{Defuzzification}

The results of the rule evaluation will be defuzzification using the centroid method to produce a single value. The determination of the formula to be used is based on expert experience about trends from existing data patterns [18].

\section{RESULT AND DISCUSSION}

\subsection{Data Acquisition}

The steps taken in the data processing are as follows:

1) Climate Data

Climate data for 2018 and 2019 were obtained from the Kampar Climatology Station, the Meteorology Climatology and Geophysics Agency (BMKG) of the Kampar Regency, which was considered to represent climate data from the Kampar District peatlands. As for climate data obtained with the following Average annual temperature: 29.75, Precipitation: $1996 \mathrm{~mm} /$ year

2) Land characteristics data

Based on the overlay results on the semi-detailed land map unit map from BBSDLP, peatland maps from Wetland, peatland maps from the Ministry of Agriculture 2017, the peatland characteristics data are obtained, namely drainage, soil texture, $\mathrm{pH} \mathrm{H} 2 \mathrm{O}$, base saturation $(\%)$, exchange capacity soil cation $(\mathrm{cmol})$, peat depth $(\mathrm{cm})$, peat maturity and slope $(\%)$.

\subsection{Knowledge Acquisition}

Table 1 explains the criteria for the suitability of pineapple peat agroecology according to Experts based on the Land Evaluation Technical Guide for Agricultural Commodities [19]. In this study, Mamdani's fuzzy logic is used to get the final result in the form of peatland suitability. There are four stages in determining the level of land suitability of crisp input values based on fuzzy inference, namely fuzzification, inference, composition, and defuzzification. The inference method used in this study is min, while the composition method used is max. The combination of these two methods is often referred to as max-min inference. Max-min inference is the most widely used method in the fuzzy inference engine because it provides convenience in computing [20]. The defuzzification method used is the centroid of the area. This method is easier to implement compared to two other methods, namely the center of gravity defuzzifier and maximum defuzzifier.

Table 1. Pineapple Peatland Suitability Criteria

\begin{tabular}{ccccc}
\hline \multirow{2}{*}{$\begin{array}{c}\text { use/characteristics } \\
\text { requirements }\end{array}$} & $\begin{array}{c}\text { S1 (Very } \\
\text { appropriate) }\end{array}$ & $\begin{array}{c}\text { S2 (Quite } \\
\text { appropriate) }\end{array}$ & $\begin{array}{c}\text { S3 } \\
\text { (Marginal } \\
\text { Accordance) }\end{array}$ & $\begin{array}{c}\text { N (It is not } \\
\text { following) }\end{array}$ \\
\hline Temperature (C) & $20-26$ & $26-30$ & $30-35$. & $>35$,
\end{tabular}




\begin{tabular}{|c|c|c|c|c|}
\hline Rainfall (mm) & $1000-1600$ & $18-20$ & $16-18$ & $<16$ \\
\hline Drainage & $\begin{array}{l}\text { good, } \\
\text { moderate }\end{array}$ & $800-1000$ & $600-800$ & $<600$ \\
\hline Soil texture & $\begin{array}{l}\text { smooth, } \\
\text { rather } \\
\text { smooth, } \\
\text { medium }\end{array}$ & $1600-2000$ & $>2000$ & $\begin{array}{l}\text { very blocked, } \\
\text { fast }\end{array}$ \\
\hline $\mathrm{pH} \mathrm{H} 2 \mathrm{O}$ & $5.0-6.5$ & $\begin{array}{l}\text { somewhat } \\
\text { inhibited }\end{array}$ & hampered, & Rough \\
\hline Base saturation (\%) & $>35$ & $\begin{array}{l}\text { rather } \\
\text { rough }\end{array}$ & rather fast & - \\
\hline CEC soil $(\mathrm{cmol})$ & $>16$ & $4.3-5.0$ & very smooth & - \\
\hline Peat Thickness $(\mathrm{cm})$ & $<50$ & $6.5-7.0$ & $<4.3$ & - \\
\hline Peat Maturity & saprik & $20-35$ & $>7.0$ & $>200$ \\
\hline Slope $(\%)$ & $<8$ & $5-16$ & $<20$ & fibric \\
\hline
\end{tabular}

Source: Ritung et al. (2011)

\subsection{Knowledge Representation}

The first stage of the Mamdani fuzzy method is the formation of a fuzzy set or known as fuzzification. The selection of fuzzy sets and the domain of each set is determined based on observations and grouping of value patterns for each parameter contained in the Technical Evaluation Manual for Agricultural Commodities [19] and interviews with Experts using the Fuzzy Inference System Mamdani method. In this study using numerical parameters and category parameters. The numerical parameters in this study consisted of average temperature, rainfall, CEC clay, $\mathrm{pH} \mathrm{H} 2 \mathrm{O}$, base saturation, peat thickness, and slope, while the category parameters consist of drainage, texture, peat maturity.

\subsection{Fuzzification}

At this stage, each input and output will be converted into linguistic variables. Truth values state the level of membership of land characteristics data in the interval of data provided. To obtain such a transformation, the data interval for crop requirements is expressed in overlapping intervals.

Overlap intervals are obtained by widening the range of the pineapple interval taking into account the validity of plant requirements. Changes in data intervals obtained through interviews with experts in the area of land suitability Experts based on their knowledge and experience provide different overlap intervals for each land characteristic. The overlap levels obtained from Experts for each of the pineapple plant land characteristics are given in Table 2. 
Table 2. Pineapple plant land suitability value parameters

\begin{tabular}{|c|c|c|c|c|c|}
\hline \multirow[t]{24}{*}{$\begin{array}{c}\text { Land } \\
\text { Characteristics } \\
\text { (Linguistic } \\
\text { Variable) }\end{array}$} & $\begin{array}{c}\text { The name of } \\
\text { the set } \\
\text { (Linguistic } \\
\text { Value) }\end{array}$ & $\begin{array}{c}\text { Data } \\
\text { Range } \\
\text { (Interval } \\
\text { ) }\end{array}$ & $\begin{array}{l}\text { Overl } \\
\text { ap }\end{array}$ & Domain & $\begin{array}{c}\text { Class } \\
\text { Land } \\
\text { Suitabi } \\
\text { lity } \\
\end{array}$ \\
\hline & Cold & $<16$ & 0.5 & {$[0,0,15.5,16.5]$} & $\mathrm{N}$ \\
\hline & Rather cold & $16-18$ & & $\begin{array}{c}{[15.5,16.5,17.5} \\
18.5]\end{array}$ & S3 \\
\hline & Cool & $18-20$ & & $\begin{array}{c}{[17.5,18.5,19.5} \\
20.5]\end{array}$ & $\mathrm{S} 2$ \\
\hline & Is & $20-26$ & & $\begin{array}{c}{[19.5,20.5,25.5} \\
26.5]\end{array}$ & S1 \\
\hline & Warm & $26-30$ & & {$[25.5,26.5,29.5$} & $\mathrm{S} 2$ \\
\hline & Hot & $30-35$ & & $\begin{array}{c}{[29.5,30.5,34.5} \\
35.5]\end{array}$ & S3 \\
\hline & Very hot & $>35$ & & $\begin{array}{c}{[34.5,35.5,40,40} \\
]\end{array}$ & $\mathrm{N}$ \\
\hline & Light & $<600$ & 50 & {$[0,0,550,650]$} & $\mathrm{N}$ \\
\hline & Mild & $\begin{array}{c}600- \\
800\end{array}$ & & $\begin{array}{c}{[550,650,750,} \\
850]\end{array}$ & $\mathrm{S} 3$ \\
\hline & Is & $\begin{array}{l}800- \\
1000\end{array}$ & & $\begin{array}{c}{[750,850,950} \\
1050]\end{array}$ & S2 \\
\hline & A little bushy & $\begin{array}{c}1000- \\
1600\end{array}$ & & $\begin{array}{c}{[950,1050,1550,} \\
1650]\end{array}$ & $\mathrm{S} 1$ \\
\hline & Heavy & $\begin{array}{c}1600- \\
2000\end{array}$ & & $\begin{array}{c}{[1550,1650,} \\
1950,2050]\end{array}$ & $\mathrm{S} 2$ \\
\hline & Very thick & $>2000$ & & $\begin{array}{l}{[1950,2050,} \\
3000,3000]\end{array}$ & S3 \\
\hline & Low & $<5$ & 0.25 & {$[0,0,4.75,5.25]$} & S3 \\
\hline & Is & $5-16$ & & $\begin{array}{c}{[4.75,5.25,15.75} \\
16.25]\end{array}$ & $\mathrm{S} 2$ \\
\hline & High & $>16$ & & $\begin{array}{c}{[15.75,16.25,20} \\
20]\end{array}$ & $\mathrm{S} 1$ \\
\hline & Acid & $<4.3$ & 0.1 & {$[0,0,4.2,4.4]$} & $\mathrm{S} 3$ \\
\hline & $\begin{array}{l}\text { Slightly } \\
\text { acidic }\end{array}$ & $4.3-5.0$ & & {$[4.2,4.4,4.9,5.1]$} & $\mathrm{S} 2$ \\
\hline & Neutral & $5.0-6.5$ & & {$[4.9,5.1,6.4,6.6]$} & $\mathrm{S} 1$ \\
\hline & $\begin{array}{l}\text { Somewhat } \\
\text { basic }\end{array}$ & $6.5-7.0$ & & {$[6.4,6.6,6.9,7.1]$} & $\mathrm{S} 2$ \\
\hline & Basa & $>7.0$ & & {$[6.9,7.1,10,10]$} & S3 \\
\hline & Low & $<20$ & 0.25 & $\begin{array}{c}{[0,0,19.75} \\
20.25]\end{array}$ & $\mathrm{S} 3$ \\
\hline & Is & $20-35$ & & $\begin{array}{l}{[19.75,20.25,} \\
34.75,35.25]\end{array}$ & $\mathrm{S} 2$ \\
\hline
\end{tabular}




\begin{tabular}{|c|c|c|c|c|c|}
\hline $\begin{array}{c}\text { Land } \\
\text { Characteristics } \\
\text { (Linguistic } \\
\text { Variable) } \\
\end{array}$ & $\begin{array}{l}\text { The name of } \\
\text { the set } \\
\text { (Linguistic } \\
\text { Value) }\end{array}$ & $\begin{array}{c}\text { Data } \\
\text { Range } \\
\text { (Interval } \\
\text { ) } \\
\end{array}$ & $\begin{array}{l}\text { Overl } \\
\text { ap }\end{array}$ & Domain & $\begin{array}{c}\text { Class } \\
\text { Land } \\
\text { Suitabi } \\
\text { lity } \\
\end{array}$ \\
\hline & High & $>35$ & \multirow{4}{*}{10} & $\begin{array}{c}{[34.75,35.25,40,} \\
40]\end{array}$ & S1 \\
\hline & Dangkal & $<50$ & & {$[0,0,40,60]$} & S1 \\
\hline & Sedang & $50-100$ & & {$[40,60,90,110]$} & S2 \\
\hline & Dalam & $\begin{array}{l}100- \\
200\end{array}$ & & $\begin{array}{c}{[90,110,190} \\
210]\end{array}$ & S3 \\
\hline & Sangat dalam & $>200$ & \multirow{4}{*}{$2 \%$} & $\begin{array}{c}{[190,210,500,} \\
500]\end{array}$ & $\mathrm{N}$ \\
\hline & Shallow & $<8$ & & {$[0,0,6,10]$} & S1 \\
\hline & Is & $8-15$ & & {$[6,10,13,17]$} & $\mathrm{S} 2$ \\
\hline & In & $15-30$ & & {$[13,17,28,32]$} & S3 \\
\hline & Very deep & $>30$ & \multirow{5}{*}{100} & {$[28,32,50,50]$} & $\mathrm{N}$ \\
\hline & Not Suitable & $<500$ & & {$[0,0,400,600]$} & $\mathrm{N}$ \\
\hline & Marginal suit & $\begin{array}{l}500- \\
1000\end{array}$ & & $\begin{array}{c}{[400,600,900,11} \\
00]\end{array}$ & $\mathrm{S} 3$ \\
\hline & $\begin{array}{c}\text { Quite } \\
\text { appropriate }\end{array}$ & $\begin{array}{c}1000- \\
1500\end{array}$ & & $\begin{array}{c}{[900,1100,1400,} \\
1600]\end{array}$ & $\mathrm{S} 2$ \\
\hline & Very suitable & $>1500$ & & $\begin{array}{c}{[1400,1600,2000} \\
, 2000]\end{array}$ & $\mathrm{S} 1$ \\
\hline
\end{tabular}

Source: [19], [21]

The membership function is a curve that shows the mapping of data input points into membership values that have intervals between 0 to 1 [22]. The membership function used is the trapezoid function. This process can be formed by comparing the input parameters and membership functions to get the membership value of each parameter, to calculate the trapezoid function. The following is a membership function of input parameters for temperature, rainfall, and land suitability output

The temperature fuzzy variable consists of 7 fuzzy sets, namely cold, cold, cool, moderate, warm, hot and very hot. The rainfall fuzzy variable consists of 6 fuzzy sets, which are mild, mild, moderate, moderately dense, dense and very dense. The land suitability fuzzy variable consists of 4 fuzzy sets, which are cold, cold, not suitable, marginal, suitable and very appropriate as illustrated in Figure 2. 


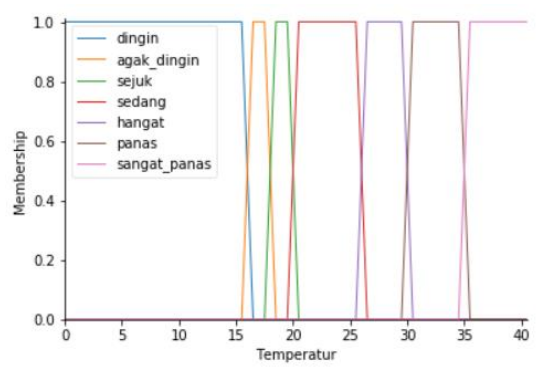

(a)

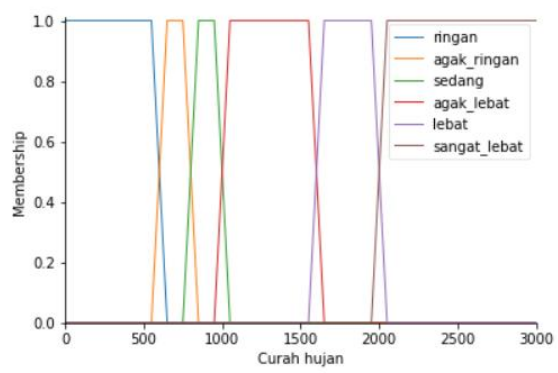

(b)

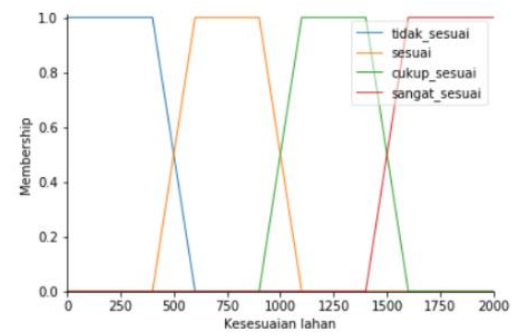

(c)

Figure 2. The membership function of temperature (a), rainfall (b) and land suitability for pineapple (c)

\subsection{Inference}

In the Fuzzy Inference System of the Mamdani type, each rule in the fuzzy knowledge base will invoke fuzzy relationships. Basic rules are made based on expert opinion. The rule parameters in this study were 95 rules in parameter 3 based on groups. In this study, there are 7 parameters that are categorized into 4 groups as follows:

1 Climate: temperature, rainfall

2 Nutrient retention: CEC clay, base saturation, $\mathrm{pH} \mathrm{H} 2 \mathrm{O}$

3 Peat: peat thickness

4 Topography: slope

To imagine the fuzzification process, an example of climate data related to climate characteristics is given: Average temperature (temp): 29.75 C and Rainfall (ch): 1996 $\mathrm{mm}$ as shown in Figure 3.

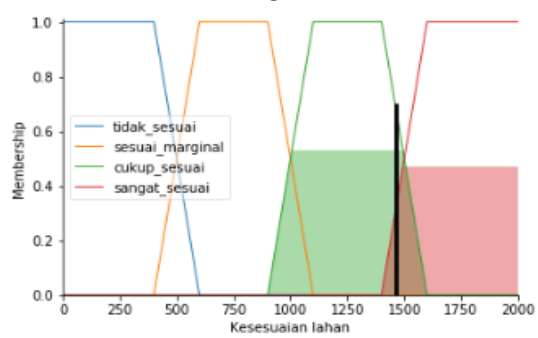

(a)

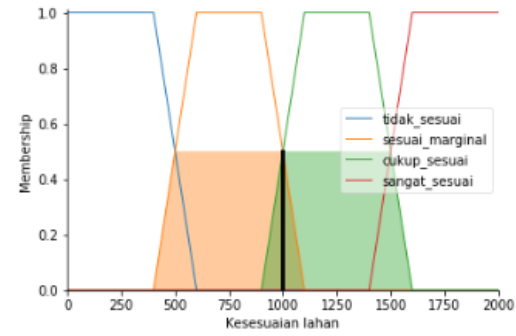

(b) 


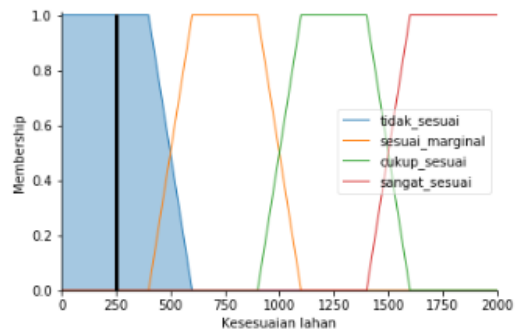

(c)

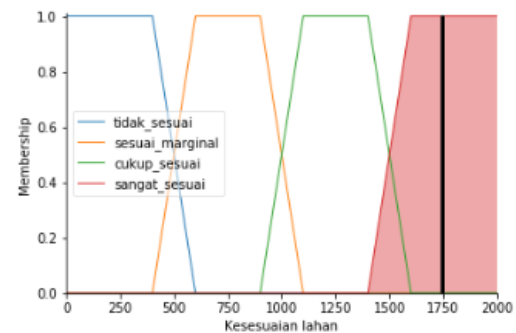

(d)

Figure 3. Fuzzy set of land suitability of climate group (a), nutrient retention (b), peatland group (c) and topography group (d) output

\subsection{Defuzzification}

The input of the defuzzification process is a fuzzy set obtained from the composition of fuzzy rules, while the resulting output is a number in the fuzzy set domain. In this study defuzzification uses the centroid of area method, in this method crisp solution is obtained by taking the center point of the fuzzy area. So for that, we count the moments for each region as shown in Figure 4.

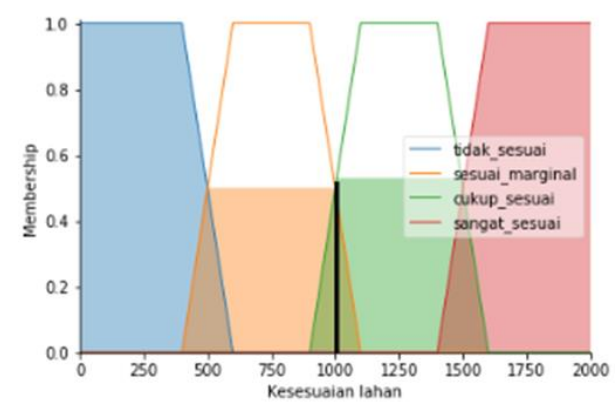

Figure 4. Fuzzy set of land suitability of peatland in pineapple plants

\section{CONCLUSION}

The main use of this research is that related agencies and agricultural extension workers can help farmers by providing information about the suitability of peatlands for pineapple plants, by the results of the Decision Support System model. This research can be developed by applying into all types of agricultural commodities such as food crops, plantations, horticulture, forestry and other commodities for peatlands by modifying parameters in the form of variables or criteria, with input models and methods used can be combined based on research needs. The model in this study can also be applied to calculate the value of peatland suitability classes in other areas by the value of the criteria or parameters of peatlands used in these other areas. 


\section{REFERENCES}

[1] Data Center and Agricultural Information System. (2016). Agriculture Commodity Outlook for Pineapple Horticulture Sub Sector. ISSN: 1907-1507. pp. 9-11

[2] BPS. (2017). Kampar Dalam Angka. Pekanbaru (ID): Central Statistics Agency of Riau.

[3] Nugroho, G. S. A., Mahi, A. K., Buchari, H. (2014). Evaluation of Qualitative and Quantitative Land Suitability for Pineapple Planting (Ananas Comosus [L.] Merr.) Makmur Farmers Group in Astomulyo Village, Punggur District, Central Lampung Regency. Journal of Tropical Agriculture, 2(1), 499-503.

[4] Sudiana, N. (2018). Area of Study and Distribution of Peatlands in Kampar Regency, Riau Province. Journal of Nature 2(1)

[5] Mubekti. (2012). Evaluation of Land Characteristics and Suitability for Plantation Commodities: Case Study of Kampar District. Journal of Environmental Engineering. 13(1), 37-46.

[6] Woda, Y. W. B. (2018). Intelligent Decision Support System for Land Suitability with Food Plant Type: Case Study of Sikka Regency. [Thesis]. Bogor (ID): Bogor Agricultural University.

[7] Sitorus, T. A. (2018). Evaluation of Land Suitability for Pineapple (Ananas Comosus L. Merr) in South Kualuh Subdistrict, North Labuhanbatu Regency [thesis]. Medan (ID): University of North Sumatra.

[8] Riyandani, D. (2016). Evaluation of Land Suitability for Various Types of Plants in Peatlands in Arut Selatan District, Kotawaringin Barat Regency [thesis]. Surakarta (ID): Muhammadiyah University, Surakarta.

[9] Hartati S, Sitanggang IS. 2010. A fuzzy-based decision support system for evaluating land suitability and selecting crops. Journal of Computer Science. 6(4), 417-424

[10] Insani, F., Sitanggang, I. S., Marimin. (2015). Expert Modeling System for Land Suitability Based on Fuzzy Genetic for Cereal Commodities: Case Study Wetland Paddy and Corn. TELKOMNIKA (Telecommunication Computing Electronics and Control), 13(3), 1047-1053

[11] Pariamanda, S., Sukmono, A., Haniah, H. (2016). Analysis of Land Suitability for Coffee Plantation in Semarang Regency. Undip Geodetic Journal, 5(1), 116-124.

[12] Nisyak, A. K., \& Ramdani, F. (2017). Web-GIS Development and Analysis of Land Suitability for Rice Plant using GIS-MCDA Method in Batu City. International Symposium on Geoinformatics. (pp. 24-33). doi: 10.1109 / ISYG.2017.8280667

[13] Kunarso, A., \& Herdiana, N. (2017). Development of Peat-Friendly Commodities in OKI Regency. Proceedings of 2017. National Suboptimal Land Seminar. ISBN: 978-979-587-748-6

[14] Soemarno. (2011). Evaluation of Land and Zoning of Agricultural, Plantation and Forestry Commodities. MK study material. Landuse Planning, PDIP PPS FPUB.

[15] Ramlan, A., Baja, S., Arif, S., Neswati, R. (2018). IOP Conference Series: Earth Environment Science, 157, 012024

[16] Moore, A., Johnson, M., Gbolagun, J., Miller, A., Rombouts, A., van der Ven L, Lord, J., Coutts, S., Pagan, M., Hall, G., B. (2018). Integrating agroecology and sustainable tourism: applying geodesign to farm management in Aotearoa New Zealand. Journal of Sustainable Tourism, 26 
[17] Marimin. (2007). Theory and Application of Expert Systems in Managerial Technology. Bogor (ID): IPB Press.

[18] Sevani, N., Marimin., Sukoco, H. (2009). Expert System for Determining Land Suitability Based on the Maximum Limitation Factor for Food Crops. Journal of Informatics, 10(1), 23-31.

[19] Ritung, S., Nugroho, K., Mulyani, A., Suryani, E. (2011). Technical Guidelines for Land Evaluation for Agricultural Commodities (Revised Edition). Indonesian Center for Agricultural Research and Development, Agricultural Research and Development Agency. Bogor. 168 things.

[20] Wang, L., X. (1997). A Course in Fuzzy Systems and Control International Edition.

[21] Djaenudin, D., Marwan, H., Subagjo, H., Hidayat, A. (2011). Technical Guidelines for Land Evaluation for Agricultural Commodities. Bogor. Indonesian Center for Agricultural Land Resources. Agricultural Research and Development Agency. Bogor

[22] Kusumadewi, S., \& Guswaludin, I. (2005). Fuzzy Multi-Criteria Decision Making. Media Informatics, 3(1) 